\title{
A constant head well permeameter formula comparison: its significance in the estimation of field-saturated hydraulic conductivity in heterogeneous shallow soils
}

\author{
*N. A. L. Archer ${ }^{1}$, M. Bonell ${ }^{2}$, A. M. MacDonald ${ }^{3}$, N. Coles $^{4}$, \\ ${ }^{1}$ British Geological Survey, Murchison House, West Mains Road, Edinburgh EH9 3LA, Scotland, UK \\ Previously at: UNESCO Centre, University of Dundee, Perth Road, Dundee DD1 4HN, Scotland, UK \\ ${ }^{2}$ UNESCO Centre, University of Dundee, Perth Road, Dundee DD1 4HN, Scotland, UK \\ ${ }^{3}$ British Geological Survey, Murchison House, West Mains Road, Edinburgh EH9 3LA, Scotland, UK \\ ${ }^{4}$ Centre for Ecohydrology, University of Western Australia, 32 Stirling Highway, Crawley WA 6009, Australia \\ *Corresponding author: nicarc@bgs.ac.uk
}

\begin{abstract}
We evaluate the application and investigate various formulae (and the associated parameter sensitivities) using the constant head well permeameter method to estimate field-saturated hydraulic conductivity $(K f S)$ in a previously glaciated temperate landscape in the Scottish Borders where shallow soils constrain the depth of augering.
\end{abstract}

In finer-textured soils, the Glover equation provided $K f s$ estimates, nearly twice those of the Richards' equation. For this environment we preferred the Glover equation with a correction factor for the effect of gravity, which does not include soil capillarity effects because: 1) the low depth to diameter ratio of the auger holes required in the shallow stratified soils of temperate glaciated environment needs a correction for gravity; 2) the persistently moist environment and the use of long pre-wetting times before measurements seem to reduce the effect of soil capillarity, 3) the Richards equation is dependent on accurate $\alpha^{*}$ values, but the measured auger holes intersected soil horizon boundaries that had different soil structure and texture, causing difficulty to select the most appropriate $\alpha^{*}$ value; 4) when comparing the different solutions to estimate $K f s$ using the CHWP method against the auger hole method and ponded permeameter measurements, the Glover solution with a correction for gravity gave the best comparable result in fine-textured soil.

Keywords | constant-head well permeameter, Guelph permeameter, hydraulic conductivity, infiltration, unsaturated soil 


\section{INTRODUCTION}

Reliable field estimates of field-saturated hydraulic conductivity $(K f s)$ (Bouwer 1966; Talsma 1987) in unsaturated soils are prerequisites for estimating water flow through soil profiles and are essential in estimating rates of soil water infiltration and soil permeability. Measurements of field-saturated hydraulic conductivity, for example, have been used to investigate land cover effects on the dominant stormflow pathways (Elsenbeer et al. 1999; Chappell et al. 2007; Bonell et al. 2010), water flow modelling and solute transport for drainage investigation (Noshadi et al. 2012), development of class pedotransfer functions (Lilly 2000) and estimating permeability of superficial deposits for characterising groundwater/surface water interactions (MacDonald et al. 2012).

The early development to more rapidly measure $K f s$ from a 'thin line source' (as defined by Talsma and Hallam 1980) using a constant-head well permeameter (CHWP) or simplified well permeameter was undertaken and described by Talsma and Hallam (1980). Through the use of the CHWP approach, $K f s$ could be more rapidly determined (Talsma and Hallam 1980; MacKenzie 2002) vis-a-vis its predecessor the 'shallow well pump-in method' (Boersma 1965; Bouwer and Jackson 1974). This instrument consists of an outer acrylic tube that contains the water for soil water infiltration and an inner smaller air entry tube. Vertical adjustable legs allow the tube to maintain a constant head height in an augered hole. The CHWP is particularly appropriate to deeply weathered soils where the water table occurs below the ground surface and the $H / a$ ratio ( $H$ being the wetted auger hole depth, $a$ being the auger hole radius) is preferably near to 10 (Talsma and Hallam 1980; Talsma 1987); see review in Mackenzie (2002). However, like its predecessor the 'shallow well pump-in method' (Talsma 1960; Bouwer and Jackson 1974), the CHWP was theoretically still based on the assumptions of the Glover solution (Zanger 1953), which corresponds to a line source from the bottom of the auger hole $(H=0)$ to the water surface $(h=H)$ with no line sink 
(Reynolds et al. 1983). The Glover solution was re-examined by Reynolds et al. (1983), who then provided improved approximations ( $C$ values) of pressure gradients derived from various line sources with various source strength distributions.

The development of the Guelph permeameter (Reynolds and Elrick 1986) later provided analytical solutions of the Richards equation, which accounts for both the apparent effect of saturated and unsaturated components of flow from an auger hole (Elrick and Reynolds 1992). Using a Guelph permeameter requires the determination of a $C$ factor and $\alpha^{*}$. This $C$ factor is a dimensionless shape factor approximating unsaturated steady-state flow out of an uncased, cylindrical hole into unsaturated soil and is derived from numerical simulations. Further, this factor is primarily a function of $H / a$ ratio and has a secondary dependence on soil type (Elrick and Reynolds 1986). The $\alpha^{*}$ parameter is the ratio of $K f s$ to matric flux potential $\left(\psi_{m}\right)$ and can be estimated using the two-ponded height technique, which uses two or more $H$ depths. Alternatively, this ratio can be determined by the oneponded height technique that a priori requires a soil description to determine the soil structure being measured which then leads to a pre-determined $\alpha^{*}$ using a 'look-up' table (Elrick et al. 1989).

Using the two-ponded height technique to estimate $\alpha^{*}$ often produces negative $K f S$ values, as was experienced by Lilly (1994) in an earlier Scottish study. Negative $K f s$ values have been attributed to random soil heterogeneities and systematic soil textural changes with depth (Salverda and Dane 1993). The one-headed technique requires soil descriptions to describe soil texture/structure to determine which $\alpha^{*}$ value to use (Elrick et al. 1989). Elsewhere Bosch (1997) investigated the sensitivity of the Guelph permeameter solution to variations of $\alpha^{*}$ and found the greatest uncertainty in error occurred in the estimate of $\alpha^{*}$ when $\alpha^{*}<0.015 \mathrm{~mm}^{-1}$, which corresponds to fine-textured and compacted clays. Bosch (1997) also calculated that the misinterpretation of describing the soil structure to be medium 
to fine sand $\left(0.012 \mathrm{~mm}^{-1}\right)$, rather than unstructured fine-textured soil $\left(0.004 \mathrm{~mm}^{-1}\right)$, could result in $K f s$ being overestimated by $140 \%$. A study by Laase (1989) compared the twoponded height technique with the one-ponded height approach, and concluded that the oneponded height technique was preferred, because it produced a smaller variance of $K f s$ results than the two-ponded height technique.

As described by Talsma (1987), overestimation of field-saturated hydraulic conductivity $(K f s)$ can occur if capillarity of the soil surrounding the saturated region of an auger hole is disregarded, and this is particularly important for fine-textured soils that have low $\alpha^{*}$ values, or $H / a$ ratios which fall below 5 (Reynolds et al. 1983). To counter such concerns, Talsma and Hallam (1980) recommended respectively a 10 or 20 minute prewetting period for auger holes inserted in 'wet' and 'dry' soils. On the other hand, in a comparative study of various field methods in gley-type soils, Chappell and Lancaster (2007) determined that of all the errors embedded within $K f s$ results, by far the most important was the smearing factor, i.e. smearing of the cavity walls as a result of augering. From early work by Talsma (1960) in an environment with marked dry/wet seasons in Australia, Talsma compared the $K f s$ ('shallow well pump-in method') with saturated hydraulic conductivity (Ksat) (auger hole pumping test) using the same auger holes. He determined the $K f_{s} / K s a t$ ratio to be about 0.5 . Later this $50 \%$ underestimation of $K s$ based on $K f s$, as determined by the CHWP (Talsma and Hallam 1980, including the Reynolds et al. (1983) correction) was further supported using data from an experimental basin study (Talsma 1987). Based on the limited range of Australian soils considered by Talsma (1987), he thus suggested the need to multiply $K f s$ by a factor of 2 . The study of Chappell and Lancaster (2007) however indicated an even greater underestimation of $K s$ in terms of orders of magnitude when concerning gley soils. 
In addition to smearing, it is also common to observe lower $K f_{s}$ values measured by the Guelph permeameter compared with other methods such as the auger hole method (Talsma 1960; Gallichand et al. 1990), undisturbed soil cores (Scotter et al. 1982; Paige and Hillel 1993; Mohanty et al. 1994), and velocity and disc permeameters (Mohanty et al. 1994). There are various reasons for these differences, such as the possibility of smaller volumes of soil being sampled by the Guelph permeameter (Mohanty et al. 1994), smearing created by augering or boring and silting-up of the hole (Talsma 1987; Koppi and Geering 1986; Chappell and Ternan 1997; Chappell and Lancaster 2007); or the lack of continuity of pores (Scotter et al. 1982), and air entrapment within the vadose zone, the latter of which slows down infiltration rates (Wang et al. 1998).

The CHWP method is recognised as being well suited to measuring deeply weathered regoliths such as those commonly found in the tropics and old landscapes (e.g. Australia, India) that have not experienced Quaternary glaciation. Less attention has been given to the application of the CHWP method in shallow soils under different land covers associated with previously heavily glaciated landscapes. Topsoils under forest and grassland have variable depths of organic horizons where horizons merge into each other within a shallow depth, and also the presence of a dynamic biological component (such as roots, detritivores and organic matter) can create larger macropores. In areas subject to glaciation, retreating ice and meltwater deposit variable amounts of clay, silt, sand and gravel within relatively small areas, creating a landscape of poorly-sorted deposits of variable particle size. As a result, the soils are heterogeneous, including coarse gravels in a fine soil matrix, silts and organic soils, some of which overlay weathered bedrock. This nature of the soils causes difficulties in classifying them into the appropriate $\alpha^{*}$ value class, as described by Elrick et al. (1989). Further, the finer silty alluvial soils pose problems for possible smearing effects by augering holes. In heterogeneous soils it is not always possible to auger below $0.15 \mathrm{~m}$, because of stony layers 
below this depth resulting in $H / a$ ratios below 5 . These circumstances cause problems in the determination of reliable $K f s$ measurements from the two-head height approach to determine $\alpha^{*}$ for different soil types.

There is therefore a requirement to investigate the most appropriate mathematical formulae for interpreting CHWP data in the heterogeneous soils common in previously glaciated areas. In this study, we explore the use of the CHWP method of Talsma and Hallam (1980) and we investigate more than one formula (and the associated various parameter sensitivities) to decide which mathematical solution is best to adopt for shallow glaciated soils. Our purpose for measuring $K f S$ is part of a study connected with Natural Flood Management (Werritty et al. 2010). A comparison of the upper soil permeability with extreme rainfalls using rainfall intensity duration frequency (IDF) was carried out and is described in Archer et al. (2013). Such an investigation required accurate and reliable $K f s$ measurements near the soil surface that are representative of field conditions. This created the basis for this paper. Thus, in this study we aim to understand how the different formulae affect the resulting $K f s$ values by carrying out a comparative analysis of results of different formulae applied to in-situ field data. We also make some preliminary measurements of $K s$ using the auger hole method (Van Beers 1985) to investigate the possible effect of auger hole smearing supplemented by surface measures of $K f s$ (Perroux and White 1988) on a flat floodplain zone.

\section{Field site}

The field site is in the Scottish Borders $\left(55^{\circ} 42.9^{\prime} \mathrm{N}, 3^{\circ} 13^{\prime} \mathrm{W}\right)$ within the Tweed catchment and is located near Eddleston village in the Eddleston Water Catchment (Fig. 1). It consists of a hillslope extending to a floodplain that varies from 0 to $22 \%$ gradient and has an altitudinal range from $192 \mathrm{~m}$ to $255 \mathrm{~m}$ (above Ordnance Datum). 
The field site area (Fig. 2) is mainly agriculturally improved grassland, where cattle and/or sheep graze from spring to autumn. In the lowest-lying depression of the floodplain, a rush community (Juncus effuses with some Ranunculus repens) dominates the gley soils. Neighbouring the steep grazed slope is a Pinus sylvestris plantation, which was planted over 45 years ago. Further upslope, west of the river, the grazed grassland area borders onto Barony Castle, set in grounds of 10 ha, which contain old remnants of woodland dating back to 1536 . Some of this woodland has been disturbed and partially cut down in the last 180 years and other areas have remained wooded for at least 500 years. Woodland species are mainly deciduous comprising of Fagus sylvatica, Prunus spinosa, Quercus petraea, Betula pendula, Acer pseudoplatanus and a few Fraxinus excelsior. Some Pinus sylvestris are also found in the woodland. Fig. 2 shows the location of measurement points that are divided into four pairs, i.e. each pair containing woodland and an adjacent grassland. Table 1 describes in detail these sites in terms of soil structure, superficial geology and land cover.

According to a recent survey of the geology (British Geological Survey 2011), there is brittle very resistant rock (Ordovician meta-sandstone greywacke), which crops out near the soil surface on parts of the hillslope. Till outcrops are located between DW2 and G2. Most measured areas are located on Head deposits, which are typically gravelly sediments, derived from local materials transported by colluvial processes, and produce poorly-sorted, stony soils. DW1 and G1 have high contents of sand, which are likely to have been brought in by glacial meltwater from the north-west. Within the floodplain (FW4 and G4) mainly silts occur which formed as overbank deposits. Also there are some beds of coarse gravel and sand within this floodplain that were laid down by laterally migrating river channels. Soil texture, measured from soil samples taken from auger holes, ranged from silt in the floodplain, fine to coarse gravels on the steeper slope, and subsequently sandy silt with some gravels on the upper flatter slopes. Clay content was relatively low throughout the site, being approximately 
$6 \%$ on the slope and up to $15 \%$ in the floodplain. The site is dominated by two Associations: Alluvium soils in the floodplain and Yarrow soils on the hillslope (Scotland Soil Survey Staff 1975), as shown in Fig. 2. The Yarrow Association on the hillslope comprises brown earths developed on gravels derived mainly from greywackes, and can be classified as Cambisols in the World Reference Bank (WRB) soil classification system (WRB 2006). The topsoil is mainly strong brown to yellow-brown stony loamy sand, and the subsoils are coarse gravel. These soils drain easily and are associated with a low water-holding capacity (Bown and Shipley 1982). The Alluvium soils are relatively young alluvial sediments developed on freshwater alluvial deposits (Fluvisols in the WRB classification), mainly consisting of silts varying with some sand and clays. Fine to coarse gravels occur throughout the soil profile. The Alluvium soils are poorly-draining depending on the occurrence of clay material and the presence of the water table in the floodplain.

\section{METHODOLOGY}

\section{Description of soil structure}

As the focus of this study was to measure $K f_{s}$ in the upper soil surface, the depths at which soil horizons changed within the shallow topsoil were noted. Some soil horizons (particularly organic horizons) changed to other horizons within $0.1 \mathrm{~m}$. To provide an understanding of such soil structure, soil descriptions were taken for each augered layer, i.e. 0 to $0.15 \mathrm{~m}$ and 0.15 to $0.25 \mathrm{~m}$.

Soil texture was determined by taking bulk samples from four auger holes in each measured area for particle-size analysis. This was undertaken by dry sieving the bulk soil samples into sieve sizes: $60 \mathrm{~mm}, 20 \mathrm{~mm}, 6.3 \mathrm{~mm}$ and $2 \mathrm{~mm}$ and the particle size distribution of material $<2 \mathrm{~mm}$ was measured using a Beckman and Coulter LS13 320 Laser Diffraction Particle Size Analyser. 


\section{Field experimental methods}

Fig. 2 shows the distribution of points where $K f s$ was measured. Three measurement techniques were available for use in the field: the constant-head well permeameter (CHWP) (Talsma and Hallam 1980), the ponded disc permeameter (PD) developed by Perroux and White (1988) and the auger hole (AH) method (Van Beers 1985). Each of these methods is well described in the literature. The application of each method for each point, where valid, was determined by field conditions as described in the following sections.

\section{CHWP method}

The CHWP was the only method used to measure $K f s$ in all sites, because it is able to measure $K f_{s}$ in areas that have steep topography and in topsoils which are above the water table. A preliminary survey of the hillslope found a gravel layer prevented augering below $0.15 \mathrm{~m}$ in the steepest part of the hillslope. So that all areas of the hillslope and floodplain could be compared, all auger holes were augered to $0.15 \mathrm{~m}$. To avoid interference from the soil surface, the CHWP was set to measure $0.04 \mathrm{~m}$ below ground surface. In the 500 year-old deciduous woodland, adjacent grassland and the floodplain, it was possible to auger another hole to $0.25 \mathrm{~m}$ because the gravel layer was deeper in these areas. Therefore, $K f s$ was measured at a soil depth between 0.15 and $0.25 \mathrm{~m}$ in these three areas (shown in Fig. 2). Before pre-wetting the auger hole for 20 minutes, pea gravel was added into the hole to prevent the cavity walls from collapsing. For very permeable soils the auger holes were prewetted for a longer time, to ensure the fall of water reached a steady-state.

\section{The AH method}

The auger hole $(\mathrm{AH})$ method measures $K s$ below the water table and is considered to measure actual $K s$, because measurements are taken below groundwater level, where soils are completely saturated. The only area where the water table was near the surface was in a 
small, marshy grassland area on the floodplain. For this reason, the AH method could be used only in a very small area (Fig. 2), where holes were augered from 0.5 to $1 \mathrm{~m}$ depths. The water in the auger hole was rapidly pumped out and then left to be replaced by groundwater. This procedure was done several times, to open the soil pores and reduce the effect of smearing. The rate of recovery was measured by the rate of rise of the water table within the auger hole.

\section{The PD method}

This method measures $K f_{s}$ at the ground surface and can be undertaken only on flat ground where the water table is at least $0.5 \mathrm{~m}$ below ground; the only area to fit these criteria was on the floodplain in area G4 (Fig. 2). Therefore in the G4 area, PD and CHWP measurements were taken at adjacent locations within $0.5 \mathrm{~m}$ of one another.

\section{Soil conditions during measurements}

Field measurements took place during two summers $(2011,2012)$, when weather conditions were dry. Initial soil water contents were measured gravimetrically from cores taken at the same time as $K f S$ measurements and capacitance probes (ThetaProbes: ML2x Delta-T, Cambridge, UK) automatically logged soil water content in the grassland. Soil water content ranged from $15 \%$ to $35 \%$. Such water contents are below field capacity in all soil types, ensuring that there was no free water available to flow into the auger holes from surrounding soil horizons.

\section{Effect of smearing}

In an attempt to avoid smearing, a hard nylon cylindrical brush was used to lightly scrape the sides of each augered hole. This was done mainly in the floodplain, where silt contents were higher, but in auger holes that contained more sand and gravel, this was not done. 
Because silty gley soils were mainly found in the floodplain and the effects of smearing for such soils have been found to introduce errors (Chappell and Lancaster 2007), we investigated the CHWP results for the floodplain in more detail. Shallow soil descriptions taken in the areas where the AH method was used (Fig. 2) were found to be similar to the grassland floodplain area (G4, Fig. 2). Because of soil similarity between the wetland and drier grassland floodplain it was considered that measurements using the $\mathrm{AH}$ method could be compared to the CHWP data from the floodplain area. However, the scope for a direct comparison between $K f s$ and $K s$ within the floodplain zone was limited, as there was only a small area in the wetland where the soils below the water table are comparable to soils above the water table in the floodplain zone. Therefore in this small area, only four auger holes could be augered to depths between $0.47 \mathrm{~m}$ and $0.77 \mathrm{~m}$.

As there was limited data from the AH method, we also compared the CHWP measurements in the floodplain zone with the results from the PD method, as it could be used as a 'benchmark' to compare $K f s$ values measured at soil depths between 0.04 and $0.15 \mathrm{~m}$. Such steps were taken because the PD method measures surface $K f s$ and does not require the augering of a hole; therefore no smearing effects occur. In making such comparisons it is acknowledged that the surface soil conditions would have relatively higher $K f_{s}$ values because of the presence of an organic layer in the top $0.04 \mathrm{~m}$ of soil surface compared with the soil between 0.04 and $0.15 \mathrm{~m}$ depth, as measured by the CHWP. On the other hand, the $K f s$ estimates measured by the PD method are biased to the vertical component of $K f s$, vis- $a$ vis the horizontal component for $K f_{s}$ (CHWP) and $K s$ (AH method), so they are strictly not comparable. Nonetheless some inferences may still be possible linked to the effect of smearing. 


\section{Investigated formulae}

For each formula investigated, the same field data from measured points (shown in Fig. 2) were used; this included: steady-state flow out of an auger hole $(Q)$, auger hole radius $(a)$ and auger hole head height $(H)$. The compared data all had $H / a$ ratios of approximately 3. $K f s$ was calculated under five categories: (1) the Glover solution (Zangar 1953) based on the Laplace equation; (2) improvements of the Glover solution, where gravity is an added component (Reynolds et al. 1983) and the pressure head distribution along the auger hole wall is numerically solved; (3) adding the component of capillarity based on the Richards equation (Elrick et al. 1989); and (4) taking away the component of capillarity using the Elrick et al. (1989) solution and calculating $K f s$ assuming only saturated flow. Finally (5) the effect of smearing (Talsma 1960; Talsma 1987) on the resulting values is investigated. Table 2 provides a key overview of the 10 variations of the solutions used to calculate $K f_{s}$ and these are described in detail below:

\section{Solution 1}

The Glover solution (Zangar 1953) is defined by:

$$
K f s=\frac{Q\left[\sinh ^{-1}\left(\frac{H}{a}-1\right)\right]}{2 H^{2}}
$$

Eq. (1)

where $Q$ is steady-state flow out of the auger hole, $H$ is auger hole head height and $a$ is auger hole head height.

\section{Solution $2 A$}

Analysis of the Glover solution theory by Reynolds et al. (1983) demonstrated that the influence of gravity to steady-state flow is inversely proportional to the square of $H / a$ ratio. This relationship, shown by Elrick and Reynolds (1992), is of particular importance when the 
ratio $H / a$ is low, as the effect of gravity on the total flow out of the well hole is $>30 \%$ when $H / a=0.5$, but falls to only $1.5 \%$ when $H / a=10$. To provide better approximations to the boundary conditions along the submerged wetted surface of the well, Reynolds et al. (1983) published improvements on the theory using Eq. 2, defined by:

$$
K f s=\frac{C Q_{t}}{2 \pi H^{2}\left[1+\frac{c}{2}\left(\frac{a}{H}\right)^{2}\right]}
$$

Based on the theory given by Reynolds et al. (1983), the shape coefficient, $C$ for the Glover solution was calculated using:

$$
C=\sinh ^{-1}\left(\frac{H}{r}\right)-\sqrt{\left(\frac{r}{H}\right)^{2}+1}+\frac{r}{H}
$$

\section{Solution $2 B$}

The influence of numerical $C$ factor was also investigated, where the steady-state pressure head distribution in a cylindrical flow area surrounding the well is solved numerically. This procedure, as explained by Reynolds et al. (1983) p.258, 'has the advantage of matching the pressure head distribution along the wall and base of the well exactly'.

\section{Solutions $3 A, 3 B, 3 C$ and $3 D$}

As the Glover solution attributes all flow out of the cavity as saturated flow, unsaturated flow (or capillary flow) is neglected. To include unsaturated flow, Elrick et al. (1989) developed the following solution: 


$$
K f s=\frac{C Q}{\left(2 \pi H^{2}+\pi a^{2} C+\frac{2 \pi H}{\alpha^{*}}\right)}
$$

The three terms in the denominator represent the approximate contributions of hydrostatic pressure, gravity and capillarity respectively. $\alpha *$ is given by

$$
\alpha^{*}={\frac{K f s}{\emptyset_{m}}}
$$

where $\varphi_{m}$ is the matric flux potential. $\alpha^{*}$ can be calculated in the field by ponding water at two different heights in the same well and then solving the simultaneous equations for $K f_{S}$ and $\varphi_{m}$ (Elrick et al. 1989), or by taking a soil description for each well to classify the soil into four textural groups described by Elrick et al. (1989), which then relates to four predefined $\alpha^{*}$ values: $0.01 \mathrm{~cm}^{-1}$ for compacted structureless, clayey or silt materials, $0.04 \mathrm{~cm}^{-1}$ for fine textured and unstructured soils, $0.12 \mathrm{~cm}^{-1}$ for structured soils from clays through loams, and $0.36 \mathrm{~cm}^{-1}$ for coarse gravelly sands, which can include highly structured soils with cracks and macropores (Elrick et al. 1989). Each soil type has a different $C$, which is dependent on the H/a ratio (Reynolds and Elrick 1987). For each of the four soil textural groups the $C$ values are based on the Richards equation and were calculated from empirical functions developed by Zhang et al. (1998).

\section{Solutions $4 A, 4 B$ and $4 C$}

To assume zero capillarity, $\alpha^{*}$ was set to infinity by setting the term $2 \pi H / C$ in Eq. 4 to zero and the $C$ factor was set to the three soil types. 


\section{Soil structure and the choice of $\alpha^{*}$ to calculate $K f$ s using Eq. 4}

Investigations which use Eq. 4 should take care to auger into homogenous soil horizons, as described by Lilly (1994). The latter excavated a soil pit to identify the horizon depths so that the wetted length, $H$ (e.g. Eq. 1) did not cross a soil horizon boundary. In this study, such steps could not be undertaken, because of the shallow nature of the soils, especially on the steeper slopes, and the organic soil horizons often merge into A horizons within shallow soil depths. This results in some auger holes intersecting more than one horizon within some of the sites and thus the wetted length $H$ invariably crosses these horizons. In such circumstances the inclusion of more than one $\alpha^{*}$ value (as provided by Elrick et al. (1989) could be used within the same auger hole. To investigate this problem, possible $\alpha^{*}$ values (as described in section 'Solutions, 3A, 3B, 3C and 3D') were used where auger holes for different sites and soil layers crossed more than one horizon. The results from using Eq. 4 with different $\alpha^{*}$ are compared with the results from using the Laplace solutions (i.e. solutions 1 and 2A), to decide the best analytical solution for measuring soils where the wetted length $H$ crosses more than one soil horizon.

\section{RESULTS}

\section{Description of topsoil structure and texture}

Table 1 summarises the auger hole soil descriptions for each site area. The depth of the organic horizon was particularly variable under the woodland areas, and because organic horizons changed to A/B horizons within the shallow layer of the topsoil, many auger holes intersected these boundaries.

\section{Field data used in the comparative analysis of different formulae}

The high diversity of soil structure and texture that also changes within shallow depths (as described in Table 1) provides a large range of steady-state flows out of the auger hole $(Q)$, 
ranging from $1 \mathrm{~mm}^{3} \mathrm{~s}^{-1}$ (in the floodplain zone) to $9,505 \mathrm{~mm}^{3} \mathrm{~s}^{-1}$ (in the old deciduous forest), as shown in Table 3. The areas of highest variability occurred in the woodland areas (Table 3).

\section{Comparative analysis of CHWP formulae to calculate $K \boldsymbol{f s}$}

Fig. 3 illustrates the calculated $K f S$ for each of the described solutions against the Glover solution (Eq. 1). In addition, Table 2 summarises the various solutions and assumptions used in the comparative analysis and the magnitude of difference between each solution against the Glover solution (Eq. 1).

Fig. 3 illustrates that the $K f s$ values calculated from the Glover solution (Eq. 1, shown as solution 1) are located midway between the Reynolds et al. (1983) solution 2B, which obtained $172 \%$ higher $K f s$ values than the Glover solution (Table 2) and the Elrick et al. (1989) solutions 3A, 3B, 3C and 3D where the addition of capillary flow for the different soil types gives lower $K f s$ values. The lower the $\alpha^{*}$ value, the lower the estimation of $K f s$ as is shown in Table 2. For example when $\alpha^{*}=0.01 \mathrm{~cm}^{-1}$, calculated $K f s$ values are $86 \%$ lower than $K f s$ values calculated by the Glover solution, whereas $\alpha^{*} \geq 0.12 \mathrm{~cm}^{-1}$ produces $K f S$ values only $21 \%$ lower than the Glover solution. Removing the effect of capillarity from the Richards equation increases the $K f s$ values up to $36 \%$ higher than the $K f s$ values calculated by the Glover solution (Table 2). The net result is that the $K f s$ values are similar to solution 2A, where the addition of the gravity flow component provides $24 \%$ higher $K f s$ values than the Glover solution (Table 2). The three shape curve factors $(C)$ cause little difference to $K f_{S}$ values, when the $H / a$ ratio is near 3 (as is the case in this study). This is because the shape factor curves are very similar at low $H / a$ ratios, as shown by Zhang et al. (1998). 


\section{Effects of soil structure and $\alpha *$ values for Eq. 4}

Table 4 compares the geometric means of calculated $K f_{s}$ values using the Richards equation (3A, 3B and 3C, Table 2) and two Glover solutions (1 and 2A, Table 2) for the different measured sites (shown in Fig. 1) and soil depths. These particular solutions were chosen because they are the most common formulae used in field research to calculate $K f s$. To calculate the Richards equation, the most appropriate $\alpha^{*}$ value for each site and soil depth was chosen on the basis of soil descriptions shown in Table 1. Sometimes two $\alpha^{*}$ values are given when the auger hole crosses two different horizons. For example, using soil descriptions for depth 0.04 to $0.15 \mathrm{~m}$ for site G2 (Fig. 4 ii), the upper half of the auger hole was considered to be more permeable than the lower part because of the soil structure, therefore the chosen $\alpha^{*}$ for the upper part of the auger hole was $0.12 \mathrm{~cm}^{-1}$ and for the lower part was $0.04 \mathrm{~cm}^{-1}$.

The results calculated from the different solutions were log transformed and plotted as box plots for each site and soil depth (Fig. 4). The resulting log transformed $K f s$ values were then analysed using analysis of variance (ANOVA) and Fisher's least significant difference (LSD) method (as described by Dytham 1999, p.108) to determine mean significance at a 95\% confidence level between the different solutions for each site and soil depth. The results of the solutions using the Fisher's LSD method are illustrated in Fig. 4. Fig. 4 is divided into i) each woodland site (DW1, DW2, CW3, FW4), ii) each grassland site (G1, G2, G3 and G4) and iii) each floodplain site (DW1, G1 and G4). The different solutions are identified on the $\mathrm{x}$-axis, as 1, 2A, 3A, 3B, 3C (and are described in Table 2). Non-shaded box plots indicate that these calculated $K f_{S}$ values have means significantly different $(P<0.05)$ to $K f_{S}$ values calculated by other solutions within each site. For example, in Fig. 4 ii) in site G2, solution $3 \mathrm{C}$ has significantly lower $K f s$ values than any of the other solutions within site G2. For the Richards equation, the chosen $\alpha^{*}$ values were considered to be high $\left(0.36 \mathrm{~cm}^{-1}\right)$ under 
woodland because of large macropores present in the upper soil layer. In the floodplain woodland (FW4), the upper 0.04 to $0.15 \mathrm{~m}$ layer intersected a more dense silt layer, therefore a lower $\alpha^{*}$ value $\left(0.12 \mathrm{~cm}^{-1}\right)$ could be considered more appropriate. However, in the woodland areas, where $K f s$ was highly variable, mean $K f s$ values calculated from the different solutions proved not significantly different.

Under grassland and at the greater soil depth $(0.15$ to $0.25 \mathrm{~m})$, the different solutions gave significantly different mean $K f s$ values. The upper soil layer (0.04 to $0.15 \mathrm{~m})$ under grassland and the lower soil layer intersected a more permeable organic layer and then a less permeable layer, therefore the choice of $\alpha^{*}$ values was not clear. The greatest significant difference between the different solutions was the Richards equation using $\alpha^{*}$ value $0.04 \mathrm{~cm}^{-1}$ in comparison to 0.12 and $0.36 \mathrm{~cm}^{-1}$, which corroborates the theoretical observations of Bosch (1997).

Fig. 4 shows that the two Glover solutions (1 and 2A) and the Richards equation using $\alpha^{*}$ value $0.36 \mathrm{~cm}^{-1}$ (solution $3 \mathrm{~A}$ ) do not result in significantly different mean $K f s$ values.

\section{Effects of smearing}

Fig. 5 shows the log transformed $K f s$ results as box plots to compare the different CHWP solutions against the $K f_{s}$ results of the $\mathrm{AH}$ and $\mathrm{PD}$ methods in the floodplain zone. Outliers were removed from the dataset, as they were considered to have been taken in gravel sediments. The three auger holes measured using the AH method had $K s$ values ranging from 5.50 to $7.34 \mathrm{~mm}$ hour $^{-1}$ and had a mean value of $6.13 \mathrm{~mm} \mathrm{hour}^{-1}$. The log transformed means of the CHWP solutions and the PD $K f s$ values were all found to be below the log mean auger hole value (Fig. 5). A two-sample T-test analysis for unequal variances compared the log transformed $K f s$ values calculated by the CHWP solutions to the AH and PD methods in the floodplain zone. All the CHWP solutions had highly significantly different $K f s$ values in comparison to the AH method $K s$ values $(P$-values $<0.05)$. Even the numerical solution $(2 \mathrm{~B})$, 
which consistently provided the highest $K f s$ values throughout the field site, had significantly lower $K f s$ values $(P$-value $=0.033)$ than the AH $K s$ values. The PD $K f s$ values were not significantly different to solutions $2 \mathrm{~A}, 2 \mathrm{~B}$ and all the Richards equations without capillary flow (4A to $4 \mathrm{C}$ ). The mean PD $K f s$ values were lower than the AH method values, but were not significantly different.

\section{DISCUSSION}

\section{CHWP Kfs solution comparison}

The lowest $K f_{s}$ values were estimated using the Richards equation, particularly using the lowest $\alpha^{*}$ value $\left(0.01 \mathrm{~cm}^{-1}\right)$, which decreased $K f s$ values by over $80 \%$ in comparison to the Glover solution (Table 2). The highest $K f s$ values were associated with the numerical solution derived by Reynolds et al. (1983) and were found to overestimate $K f s$ values by about $170 \%$ over the Glover solution, corroborating results previously noted by Reynolds et al. (1983). However, for the most commonly used solutions, i.e. Glover solutions (1 and 2A) and Richards equations (3A and 3B), the results show that for many situations in the field site there is little significant difference in $K f s$ calculated using these different solutions (Fig. 4). It is only when the soil type becomes more silty, creating a soil description which suggests a lower $\alpha^{*}$ value, that difficulties arise. Here the choice of $\alpha^{*}$ values are found to make significant differences to mean $K f s$ values (Fig. 4). In the case of this study, this has particular importance because, as described in the methodology, the measured auger holes intersected two different horizons, and it is difficult to select an absolute $\alpha^{*}$ value for all experimental areas. This could result in significant over or under estimation of $K f s$, particularly if there is confusion between choosing an $\alpha^{*}$ value of 0.04 or $0.12 \mathrm{~cm}^{-1}$. On the other hand, solution $2 \mathrm{~A}$ gives consistently higher $K f_{s}$ values and is the most comparable to the Richards equation $3 \mathrm{~A}$, where capillary flow has the least influence. 


\section{Choosing the 'best' solution}

To choose the 'best' solution, three important site features that are relevant to $K f s$ measurements were considered:

1) Initial soil water content: soil water contents were below field capacity, but they were moist and therefore quickly wetted-up, unlike dry soils in arid environments. Auger holes were also pre-wetted for at least 20 to 30 minutes to attain steady-state (following Talsma and Hallam 1980). In combination, these two soil factors would minimise the effects of soil capillarity and therefore it is plausible to assume near-zero capillarity effects.

2) Soil type: as outlined in the study site description, the soils measured for $K f s$ were variable not only in soil texture and structure, but also in terms of biological activity where the presence of shallow dense root mats under grassland and deep coarse roots under forest were significantly different. The glacial alluvial soils were also heterogeneous particularly within the surface profile $(0.04$ to $0.15 \mathrm{~m})$ and at some measurement locations the auger hole intersected more than one horizon. This causes more than one soil textural group to occur within one auger hole, which makes selecting the most appropriate $\alpha^{*}$ more problematic. Thus, there exists uncertainty in the appropriate selection of $\alpha^{*}$ at some points.

3) H/a ratio: Elrick et al. (1989) observed that $K f s$ measured using the Guelph permeameter is least sensitive to the choice of $\alpha^{*}$ when $H$ is large. In cases where $H$ incorporates two soil horizons and the $H$ parameter is small, a question arises as to the reliability of using $\alpha^{*}$ values to estimate $K f$ s for this investigation. The particularly low $H / a$ ratio also meant that gravity had a relatively large effect on $K f s$ values, as explained by Elrick and Reynolds (1992). Therefore the original Glover solution, which does not include the effect of gravity, was inappropriate to estimate $K f s$. 
Taking into account the results given in Figs. 3 and 4 and Tables 2 to 4 , the field conditions, and the low H/a ratios for the auger holes measured, solution 2A (the Glover solution corrected for the effect of gravity) was selected as the preferred method to provide the most representative $K f S$ values for the study area. Solution $2 \mathrm{~A}$ was thus subsequently adopted for comparison of measured $K f s$ to rainfall intensity-duration-frequency curves to infer dominant stormflow pathways (Chapell et al. 2007), as undertaken by Archer et al. (2013).

It was also useful to examine the effect of $\alpha^{*}$ values set to infinity, to remove the effect of capillarity (solutions 4A, 4B and 4C), as this was considered to produce maximum $K f s$ values as described by Elrick et al. (1989). As the $K f s$ values calculated from solution 2A are lower than the resulting $K f s$ values calculated by solutions $4 \mathrm{~A}$, $4 \mathrm{~B}$ and $4 \mathrm{C}$, it was therefore considered that solution $2 \mathrm{~A}$ was not overestimating $K f s$. The numerical correction (solution $2 \mathrm{~B})$, on the other hand, is considered to overestimate $K f s$ values even though it was found to produce estimates of $K f s$ closer to the air entry method (Reynolds et al. 1983).

\section{Effect of smearing and the over/under-estimation of CHWP $K f s$ values}

The significant differences between the $K s$ values measured by the AH method and the $K f s$ resulting from CHWP solutions (but accepting the constraint of a small $\mathrm{AH}$ sample) suggest that the effect of smearing caused underestimation of $K f s$ in the floodplain zone, where the alluvial soils had a finer matrix. When comparing the auger hole method to the CHWP results using the Glover solution, Talsma (1987) suggested a correction factor by multiplying the CHWP results by 2 to correct for smearing on Laplace solutions. In this study if we multiply solutions 1, 2A and 2B (variations of Laplace solutions) by 2, then solution 2B provides the closest mean $K f s$ value to the auger hole method, thus corroborating Talsma's (1987) conclusions. 
Following on from the above findings, it is interesting to note the contrasts by other researchers in the over/underestimation of $K f s$ when comparing the other methods with solutions. According to Reynolds et al. 1983, the CHWP method using the Laplace solutions, i.e. the Glover solution, overestimates $K f S$ when compared to the Richards equation, but according to Talsma (1987) the CHWP method using the Glover solution underestimates $K f_{S}$ in comparison to the AH method (Talsma 1987). Even though the Richards equation provides the lowest $K f_{s}$ of all the solutions in most studies, it is the main solution used to estimate in situ Kfs in the UK (Ragab and Cooper 1993; Lilly 1994; Chandler and Chappell 2008; Marshall et al. 2009; MacDonald et al. 2012). It is also worth noting that other studies have multiplied the Guelph permeameter values (calculated using the Richards solution) by 2 to obtain similar $K s$ values to the auger hole method (Noshadi et al. 2012), which they attribute to air entrapment (Bouwer 1978, p. 45).

A comparison of the surface soil $K f s$ using the PD method, to the $K f s$ as calculated by the preferred CHWP Glover solution with the effect of gravity included (solution 2A), indicates similar results. This outcome adds strength to the argument against multiplying the $K f s$ values in the floodplain zone by a factor of 2. If smearing was an issue, it would have been expected that the surface $K f s$ values (measured by the PD method) would be significantly higher than the $K f s$ values measured by the CHWP under moist soil conditions. Such remarks remain valid despite bias in the respective PD and CHWP methods towards different $K f s$ components, i.e. vertical vis-a-vis horizontal.

The low $K f s$ values estimated by the Richards equation are more of a concern considering its wide use in the UK and the dependency on soil descriptions for predetermined $\alpha^{*}$ values (Lilly 1994; Marshall et al. 2009; MacDonald et al. 2012). In this study the high silt content in the floodplain (G4) suggests an $\alpha^{*}$ value of $0.04 \mathrm{~cm}^{-1}$ at a depth below $0.15 \mathrm{~m}$. If we used the Richards equation with this low $\alpha^{*}$ value, the resulting $K f s$ values 
would be significantly lower than the $K f S$ values of the AH method (as shown in Fig. 5). This suggests that the effect of capillarity may not be such an issue.

In humid temperate regions where rainfall is relatively high and potential evaporation is low, moist antecedent soil conditions often close to field capacity can prevail. In such conditions, the effect of capillary flow may not be so great when measuring $K f s$ and therefore the use of the Richards equation may cause underestimation of $K f s$. Acknowledging the persistent moist soil conditions, particularly in Scotland, saturated soil conditions enveloping auger holes should easily be reached by adding water to the cavity for 20 minutes.

Considering also the high soil structural and textural variability and the dependency of the Richards equation on an accurate estimate of $\alpha^{*}$, the Glover solution may be more appropriate in such soil conditions.

The highest Kfs values recorded in this study were related to organic forest soils, which include high macro-porosity due to the presence of relatively large diameter roots, and were considered to cause some preferential flow. Germann et al. (2007) suggest that preferential infiltration is positioned between the domains of the Richards equation and Darcy's law, and as suggested by Beven \& Germann (2013), 'macropores carry water quite independently from antecedent soil moisture and capillary flow'. The Richards equation may therefore cause underestimations of macropore flow measured by the CHWP, so the Laplace equations may be more appropriate. However, all the equations tested ignore preferential flow, which is an important aspect particularly under forests, as experienced in this study, where organic horizons are deep and tree root systems are extensive, causing preferential flow pathways. 


\section{CONCLUSION}

This comparative study illustrates the importance of understanding the antecedent soil conditions, the assumptions of existing $K f s$ equations and the environmental conditions which limit the way $K f s$ measurements are undertaken.

We found that in many situations, the results of the Glover solutions were not significantly different to the Richards equation when soil was mainly well structured or gravelly sand, providing higher $\alpha^{*}$ values, $\left(0.36\right.$ and $\left.0.12 \mathrm{~cm}^{-1}\right)$. However, in situations where silt contents were high, the Glover solutions estimated significantly higher $K f_{s}(P<0.05)$, when $\alpha^{*}$ values were lower $\left(<0.04 \mathrm{~cm}^{-1}\right)$ in the Richards equation.

With this particular investigation in mind we considered that solution $2 \mathrm{~A}$, i.e. the Glover solution with gravity taken in account (Reynolds et al. 1983), was preferred for the following reasons:

- The Richards equation is dependent on accurate $\alpha^{*}$ values, but the measured auger holes intersected soil horizon boundaries that had different soil structure and texture. Such circumstances caused difficulties within the framework of the pre-existing classification of Elrick et al. (1989) to select the most appropriate $\alpha^{*}$ value.

- Overestimation of solution 2A was considered to be minimal, because the resulting $K f S$ values were lower than solutions $4 \mathrm{~A}, 4 \mathrm{~B}$ and $4 \mathrm{C}$ (where capillarity was 0 for different soil types), which provided maximum $K f S$ values as described by Elrick et al. (1989).

- Within the floodplain zone where silty soils were present, $K f s$ values estimated from the CHWP method using solution 2A were significantly lower $(P>0.05)$ than estimates from the AH method, but not significantly lower than the PD method. This suggests that there were some smearing effects occurring in the floodplain zone using 
the CHWP method. However, as there was no order of magnitude difference in $K f S$ between these methods, unlike reports from other studies (Chappell and Lancaster 2007), the CHWP method using solution 2A was considered to give broadly representative $K f s$ values.

- Unsaturated flow could also be negligible because of the moist (not far below field capacity) soil conditions and the pre-wetting of auger holes before taking measurements, following Talsma and Hallam (1980).

Taking into account various requirements for representative $K f s$ data, field conditions, constraints on measuring $K f s$ and assumptions of each solution, this study is an example of how appropriate solutions to estimate $K f s$ were chosen. The $K f s$ results secured from this study have subsequently been compared with rainfall intensity duration frequency data to infer storm runoff generation processes and are described in detail in Archer et al. (2013).

However, none of these solutions take into account preferential flow, which could cause an underestimation of $K f s$ for all solutions. This aspect needs to be taken into account, particularly in soils that have a network of root systems, are highly organic and are biologically active, which can cause high macropore connectivity and result in preferential flow.

\section{ACKNOWLEDGEMENTS}

This research is part of the Eddleston Water Project - Phase II, which is funded by the Scottish Government. In particular we are grateful to the University of Western Australia for additional funding and equipment on which the fieldwork depended. This paper is published with the permission of the Executive Director of the British Geological Survey (NERC). 


\section{REFERENCES}

Archer, N.A.L., Bonell, M., MacDonald, A.M., Auton, C., Coles, N. \& Stevenson, R. 2013 Soil characteristics and landcover relationships on soil hydraulic conductivity at a hillslope scale: A view towards loacal flood managment. J. Hydrol. 497, 208-222.

Beven, K \& Germann, P. 2013. Macropores and water flow in soils revisited. Water Resour Res. 49, 3071-3092

Boersma, L., 1965 Field measurement of hydraulic conductivity above a water table. In: Methods of Soil Analysis (C.A. Black, ed.). Agronomy 9, American Society of Agronomy, Madison, Wisconsin, pp. 234-252.

Bonell, M., Purandara, B.K., Venkatesh, B. Krishnaswamy, J., Acharya, H.A.K., Singh, U.V., Jayakumar, R. \& Chappell, N. 2010 The impact of forest use and reforestation on soil hydraulic conductivity in the Western Ghats of India: Implications for surface and sub-surface hydrology. J. Hydrol. 391, 47-62.

Bosch, D.D. 1997 Constant head permeameter formula dependence on alpha parameter. $T$. Am. Soc. Agri. Eng. 40, 1377-1379.

Bouwer, H., 1966. Rapid field measurement of air entry value and hydraulic conductivity of soil as signifiant paprameters in flow system analysis. Water Resour. Res. 2, 729-723.

Bouwer, H. 1978 Groundwater Hydrology. New York: McGraw-Hill, Inc, USA. 480 pp. Bouwer, H. \& Jackson, R.D. 1974 Determining soil properties. In: Drainage for Agriculture. Vol. 17. (J.V. Schilfgaarde, ed). American Society of Agronomy, Madison, Wisconsin, pp. 611-666.

Bown, C.J. \& Shipley, B.M. 1982 Soil Survey of Scotland: South-East Scotland, 1:250 000 Sheet 7. The Macaulay Institute for Soil Research, Aberdeen, University Press, Aberdeen. 
British Geological Survey 2011 Eddleston Water Catchment: Superficial Geology 1:25 000 Scale. British Geological Survey, Keyworth, Nottingham.

Chandler, K.R. \& Chappell, N.A. 2008 Influence of individual oak (Quercus robur) trees on saturated hydraulic conductivity. Forest Ecol. Manag. 256,1222-1229.

Chappell, N.A. \& Lancaster J.W. 2007 Comparison of methodological uncertainties within permeability measurements. Hydrol. Process. 21, 2504-2514.

Chappell, N.A., Sherlock, M., Bidin, K., Macdonald, R., Najman, Y. \& Davis, G. 2007 Runoff processes in Southeast Asia: role of soil, regolith, and rock type. In: Forest Environments in the Mekong River Basin. (H. Swada, M. Araki, N.A. Chappell, J.V. LaFrankie \& A. Shimizu, eds.) Tokyo: Springer-Verlag, pp. 2-23.

Chappell, N.A. \& Ternan, J.L. 1997 Ring permeametry: Design, operation and error analysis. Earth Surf. Proc. Land. 22, 1197-1205.

Elrick, D.E. \& Reynolds, W.D. 1986 An analysis of the percolation test based on threedimensional saturated-unsaturated flow from a cylindrical test hole. Soil Sci. 142, $308-321$.

Elrick, D.E. \& Reynolds, W.D. 1992 Methods for analyzing constant-head well permeameter data. Soil Sci. Soc. Am. J. 56, 320-323.

Elrick, D.E., Reynolds ,W.D. \& Tan, K.A. 1989 Hydraulic conductivity measurements in the unsaturated zone using improved well analyses. Ground Water Monit. Rev. 9, 184193.

Elsenbeer, H., Newton, B., Dunne, T. \& de Mores, J. 1999 Soil hydraulic conductivities of latosols under pasture, forest and teak in Rondonia, Brazil. Hydrol. Process. 13, 1417 1422. 
Gallichand, J., Madramootoo, C., Enright, P. \& Barrington, S. 1990 An evaluation of the Guelph permeameter for measuring saturated hydraulic conductivity. Trans ASAE . 33, (4), 1179-1184.

Germann, P., Helbling, A. \& Vadilonga, T. 2007 Rivulet approach to rates of preferential infiltration. Vadose Zone J. 6, 207-220.

Koppi, A.J. \& Geering, H.R. 1986 The preparation of unsmeared soil surfaces and an improved apparatus for infiltration measurements. J. Soil Sci. 37, 177-181.

Laase, A.D. 1989 A critical evaluation of borehole permeameter solutions. New Mexico Institute of Mining and Technology. Master of Science of Hydrology, Socorro, New Mexico, 180.

Lilly, A. 1994 The determination of field-saturated hydraulic conductivity in some Scottish soils using the Guelph permeameter. Soil Use Manag. 10, 72-78.

Lilly, A. 2000 The relationship between field-saturated hydraulic conductivity and soil structure: development of class pedotransfer functions. Soil Use Manag. 16, 56-60.

MacDonald, A.M., Maurice, L., Dobbs, M.R., Reeves, H.J. \& Auton, C.A. 2012 Relating in situ hydraulic conductivity, particle size and relative density of superficial deposits in a heterogeneous catchment. J. Hydrol. 434-435, 130-141.

MacKenzie, D.H., 2002. Field measurement of saturated hydraulic conductivity using the well permeameter. In: Soil Physical Measurement and Interpretation for Land Evaluation (N. McKenzie, K. Coughlan \& H. Cresswell, eds.). CSIRO Publishing, Melbourne, pp. 131-149.

Marshall, M.R., Francis, O.J., Frogbrook, Z.L., Jackson, B.M., McIntyre, N., Reynolds, B., Solloway, I., Wheater, H.S. \& Chell, J. 2009 The impact of upland land management on flooding: Results from an improved pasture hillslope. Hydrol. Process. 23, 464475. 
Mohanty, B.P., Kanwar, R.S. \& Everts, C.J. 1994 Comparison of saturated hydraulic conductivty measurement methods for a glacial-till soil. Soil Sci. Soc. Am. J. 58, 672677.

Noshadi, M., Parvizi, H. \& Sepaskhah, A.R. 2012 Evaluation of different methods for measuring field-saturated hydraulic conductivity under high and low water table. Vadose Zone J. 11 (1). doi:10.2136/vzj2011.0005 doi: 10.2136/vzj2011.0005

Paige, G.B. \& Hillel, D. 1993 Comparison of three methods for assessing soil hydraulic properties. Soil Sci. 155, 175-189.

Perroux, K.M. \& White, I. 1988 Designs for disc permeameters. Soil Sci. Soc. Am. J. 52, 1205-1215.

Ragab, R. \& Cooper, J.D. 1993 Variability of unsaturated zone water transport parameters: implications for hydrological modelling. 1. In situ measurements. J. Hydrol. 148, 109131.

Reynolds, W.D. \& Elrick D.E. 1986 A method for simultaneous in situ measurement in the vadose zone of field-saturated hydraulic conductivity, sorptivity and the conductivitypressure head relationship. Ground Water Monit. Rev. 6, 84-95.

Reynolds, W.D., Elrick, D.E. \& Topp, G.C. 1983 A reexamination of the constant head well permeameter method for measuring saturated hydraulic conductivity above the water table. Soil Sci. 136, 250-268.

Salverda, A.P. \& Dane, J.H. 1993 An examination of the Guelph permeameter for measuring the soil's hydraulic properties. Geoderma 57, 405-421.

Scotter, D.R., Clothier, B.E. \& Harper, E.R. 1982 Measuring saturated hydraulic conductivity and sorptivity using twin rings. Aust. J. Soil Res. 20, 295-304. 
Soil Survey of Scotland Staff 1975 Peebles soil map: Soil survey of Scotland, systematic soil survey; sheet $24 \&$ part of sheet 32. Scale 1:250 000. Soil Survey of Scotland, Macaulay Institute, Aberdeen, UK.

Talsma, T. 1960 Comparison of field methods of measuring hydraulic conductivity. In Int. Comm. Irrig. Drainage 4th Congress, Madrid, Spain. 145-156.

Talsma, T. 1987 Re-evaluation of the well permeameter as a field method for measuring hydraulic conductivity. Aust. J. Soil Res. 25, 361-368.

Talsma, T. \& Hallam, P.M. 1980 Hydraulic conductivity measurement of forest catchments. Aust. J. Soil Res. 18, 139-148.

Van Beers, W.F.J. 1985 The Auger Hole Method: A Field Measurement of the Hydraulic Conductivity of Soil Below the Water Table (6 $6^{\text {th }}$ Edition). International Institute for Land Reclamation and Improvement/ ILRI, P.O. Box 45, 6700 AA Wageningen, The Netherlands.

Wang, Z., Feyen, J., Van Genuchten, M.T. \& Nielsen, D.R. 1998 Air entrapment effects on infiltration rate and flow instability. Water Resour. Res. 34, 213-222.

Werritty, A., Ball, T., Spray, C., Bonell, M., Rouillard, J. \& Archer, N.A.L. 2010 Restoration strategy: Eddleston Water scoping study Final Report 2010. http://www.tweedforum.org/projects/current-projects/FinalReportpdf

World Reference Bank (WRB), IUSS Working Group 2006 World reference base for soil resoures 2006. World Soil Resources Reports No. 103. FAO, Rome.

Zangar, C.N. 1953. Theory and problems of water percolation. Engineering Monographs No. 8. United States Department of the Interior, Bureau of Reclamation, Denver, Colorado. USA 
Zhang, Z.F., Groenevelt, P.H. \& Parkin, G.W. 1998 The well-shape factor for the measurement of soil hydraulic properties using the Guelph Permeameter. Soil and Tillage Res. 49, 219-221.

First received 25 September 2012; accepted in revised form 22 January 2014. Available online 


\begin{tabular}{|c|c|c|c|c|}
\hline $\begin{array}{l}\text { Site } \\
\text { area }\end{array}$ & Description & Topsoil Description & Soil structure and texture & Superficial Geology \\
\hline G1 & $\begin{array}{l}\text { Improved grassland } \\
>265 \text { years }\end{array}$ & $\begin{array}{l}0 \text { to } 0.04 \mathrm{~m} \text { grass root mat. A horizon extends from } 0.05 \\
\text { to } 0.25 \mathrm{~m} \text { and grades into a B Horizon. Gravels exist } \\
\text { throughout, but coarse gravel increases in the B horizon } \\
\text { below } 0.25 \mathrm{~m} \text { depth. }\end{array}$ & $\begin{array}{l}\text { Loamy sand. Granular, crumb } \\
\text { structure } 0 \text { to } 0.04 \mathrm{~m} \text {, becomes sub } \\
\text { angular blocky around } 0.2 \mathrm{~m} \text {. }\end{array}$ & $\begin{array}{l}\text { Glaciofluvial gravel } \\
\text { and sand }\end{array}$ \\
\hline DW1 & $\begin{array}{l}\text { Deciduous } \\
\text { Woodland, mature } \\
\text { Beech }>500 \text { years }\end{array}$ & $\begin{array}{l}0 \text { to } 0.10 \mathrm{~m} \text { litter layer. Humus layer up to } 0.05 \mathrm{~m} \text {. } \\
\text { Organic layer extends to } 0.15 \text { grading into A horizon } \\
\text { between } 0.15 \mathrm{~m} \text { to } 0.30 \mathrm{~m} \text {. Gravel B Horizon extends into } \\
\text { A horizon around } 0.25 \mathrm{~m} \text {. Organic horizons variable } \\
\text { depending on distance from trees. Gravels increase } \\
\text { around } 0.25 \mathrm{~m} \text { depth. }\end{array}$ & $\begin{array}{l}\text { Loamy sand. Granular, crumb, } \\
\text { structure to depths over } 0.2 \mathrm{~m} \text {, } \\
\text { below this depth can become } \\
\text { blocky or structureless, depending } \\
\text { on sand content and presence of } \\
\text { roots }\end{array}$ & $\begin{array}{l}\text { Glaciofluvial gravel } \\
\text { and sand }\end{array}$ \\
\hline G2 & $\begin{array}{l}\text { Improved grassland } \\
>265 \text { years }\end{array}$ & $\begin{array}{l}\text { Dense grass root mat } 0 \text { to } 0.05 \mathrm{~m} \text {. A horizon to } 0.20 \mathrm{~m} \text {. } \\
\text { Coarse gravel throughout profile, at variable depth } \\
\text { increasing from } 0.20 \mathrm{~m} .\end{array}$ & $\begin{array}{l}\text { Sandy loam. Granular, crumb } \\
\text { structure } 0 \text { to } 0.4 \mathrm{~m} \text {, becomes sub } \\
\text { angular blocky around } 0.2 \mathrm{~m} \text {. }\end{array}$ & $\begin{array}{l}\text { Till occurring within } \\
\text { the upper half of the } \\
\text { site area. The rest of } \\
\text { the area underlain by } \\
\text { Head. }\end{array}$ \\
\hline DW2 & $\begin{array}{l}\text { Deciduous mixed } \\
\text { woodland }<160 \\
\text { years }\end{array}$ & $\begin{array}{l}0 \text { to } 0.05 \mathrm{~m} \text { litter layer. Humus layer variable thickness } \\
\text { from } 0.01 \text { to } 0.05 \mathrm{~m} \text {. Organic layer between } 0.10 \mathrm{~m} \text { to } \\
\text { below } 0.20 \mathrm{~m} \text { depth, extending into A horizon. Organic } \\
\text { horizons variable depending on distance from trees. } \\
\text { Gravels exist throughout, but increase around } 0.20 \mathrm{~m} \text {. }\end{array}$ & $\begin{array}{l}\text { Sandy loam. Granular, crumb, } \\
\text { structure to depths over } 0.15 \mathrm{~m} \text {, } \\
\text { below this depth can become } \\
\text { blocky or structureless, depending } \\
\text { on sand content and presence of } \\
\text { roots }\end{array}$ & $\begin{array}{l}\text { Till occurring within } \\
\text { the lower half of the } \\
\text { site area. The rest of } \\
\text { the area is underlain by } \\
\text { Head. }\end{array}$ \\
\hline G3 & $\begin{array}{l}\text { Improved grassland } \\
>265 \text { years }\end{array}$ & $\begin{array}{l}\text { Dense grass root mat } 0 \text { to } 0.05 \mathrm{~m} \text {. Silty A horizon extends } \\
\text { to around } 0.20 \mathrm{~m} \text {. Coarse gravel throughout profile, } \\
\text { increasing at } 0.20 \mathrm{~m} \text {. }\end{array}$ & $\begin{array}{l}\text { Sandy loam. Granular, structure } 0 \\
\text { to } 0.05 \mathrm{~m} \text { becomes sub angular } \\
\text { blocky around } 0.1 \mathrm{~m} \text {. }\end{array}$ & $\begin{array}{l}\text { Gravels derived from } \\
\text { bedrock }\end{array}$ \\
\hline CW3 & $\begin{array}{l}\text { Conifer plantation } \\
50 \text { years }\end{array}$ & $\begin{array}{l}0 \text { to } 0.05 \mathrm{~m} \text { litter layer. Dark humus layer variable } \\
\text { thickness from } 0.01 \text { to } 0.05 \mathrm{~m} \text {. Organic silt A horizon } \\
\text { extends from } 0.10 \mathrm{~m} \text { to below } 0.15 \mathrm{~m} \text { and colour changes } \\
\text { to red-brown, showing possible illuviation of organic } \\
\text { colloids. Cobbles present from } 0.15 \mathrm{~m} \text { grading into a B }\end{array}$ & $\begin{array}{l}\text { Sandy loam. Granular, crumb } \\
\text { structure } 1 \text { to } 0.15 \mathrm{~m} \text {. Becomes } \\
\text { blocky below } 0.15 \mathrm{~m}\end{array}$ & $\begin{array}{l}\text { Gravels derived from } \\
\text { bedrock }\end{array}$ \\
\hline
\end{tabular}


horizon and in some points reaching a shallow $\mathrm{C}$ horizon.

\begin{tabular}{lllll} 
G4 & $\begin{array}{l}\text { Improved grassland } \\
>265 \text { years }\end{array}$ & $\begin{array}{l}0 \text { to } 0.04 \mathrm{~m} \text { organic layer. Clay silt A horizon extends } \\
\text { between } 0.04 \mathrm{~m} \text { to below } 0.3 \mathrm{~m} \text {. Gravel occasionally } \\
\text { present from } 0.2 \mathrm{~m} \text {. Some gleying below } 0.2 \mathrm{~m} .\end{array}$ & $\begin{array}{l}\text { Loam. Granular, crumb structure } 0 \\
\text { to } 0.04 \mathrm{~m} \text {. Becomes unstructured } \\
\text { around } 0.1 \mathrm{~m} .\end{array}$ & $\begin{array}{l}\text { Recent riverine alluvial } \\
\text { deposits }\end{array}$ \\
FW4 & $\begin{array}{l}\text { Deciduous } \\
\text { Woodland, mature } \\
\text { Willows }<180 \\
\text { years }\end{array}$ & $\begin{array}{l}0 \text { to } 0.08 \mathrm{~m} \text {, highly heterogeneous organic layer. A } \\
\text { horizon extends from } 0.08 \mathrm{~m} \text { to below } 0.3 \mathrm{~m} \text {. Areas of } \\
\text { gleying occur around } 0.015 \mathrm{~m} \text { soil depth. }\end{array}$ & $\begin{array}{l}\text { Loam. Granular structure } 0 \text { to } 0.1 \\
\mathrm{~m} \text {, becomes unstructured } 0.1 \text { to } \\
0.15 \mathrm{~m} .\end{array}$ & $\begin{array}{l}\text { Recent riverine alluvial } \\
\text { deposits }\end{array}$ \\
\hline
\end{tabular}

Table 1) Summary of soils measured for each site area, describing soil horizons, texture, structure and superficial geology. The mix of letters indicate: $\mathrm{G}$ is grassland cover, $\mathrm{W}$ relates to woodland cover, $\mathrm{D}$ is deciduous woodland, $\mathrm{C}$ is conifer and $\mathrm{F}$ is floodplain. 


\begin{tabular}{|c|c|c|c|c|}
\hline $\begin{array}{l}\text { Solution } \\
\text { ID }\end{array}$ & Reference & $K f s$ Eq. and $C$ factor formulae & Assumptions & $\begin{array}{l}\text { Percentage } \\
\text { difference to } \\
\text { Eq. } 1\end{array}$ \\
\hline 1 & $\begin{array}{l}\text { Glover solution (Eq. } 3 \\
\text { and 4, p.320 Elrick and } \\
\text { Reynolds (1992) }\end{array}$ & $\begin{aligned} \dagger K f s= & C Q /\left(2 \pi H^{2}\right) \\
C & =\sinh ^{-1}\left(\frac{H}{a}\right)-\left(\frac{a^{2}}{H^{2}}+1\right)^{\frac{1}{2}}+2 / H\end{aligned}$ & $\begin{array}{l}\text { Saturated flow, capillarity is zero } \\
\text { and flow as a component of gravity } \\
\text { is negligible, based on the Laplace } \\
\text { solution. }\end{array}$ & \\
\hline $2 \mathrm{~A}$ & $\begin{array}{l}\text { Glover solution (Eq. 2) } \\
\text { C factor calculated from } \\
\text { Eq. 3. (Reynolds et al. } \\
\text { 1983) }\end{array}$ & $\begin{array}{c}K_{f s}=\mathrm{CQ} / 2 \pi \mathrm{H}^{2}\left[1+C / 2\left(\frac{a}{H}\right)^{2}\right] \\
C=\sinh ^{-1}(H / a)-\sqrt{(H / r)^{2}+1}+a / H\end{array}$ & $\begin{array}{l}\text { Saturated flow, capillarity is zero } \\
\text { and component of gravity added } \\
\text { based on the Laplace solution. }\end{array}$ & $+24 \%$ \\
\hline 2B & $\begin{array}{l}\text { Glover solution. } C \text { factor } \\
\text { calculated from the } \\
\text { numerical solution } \\
\text { (Reynolds } \text { et al. } 1983 \text { ) }\end{array}$ & $\begin{array}{l}\text { The numerical factor } C \text { for } H / a=3 \text { in saturated } \\
\text { conditions was estimated from Fig. } 1 \text { p.321 (Elrick } \\
\text { and Reynolds 1992). }\end{array}$ & $\begin{array}{l}\text { Saturated flow, capillarity is zero } \\
\text { and component of gravity added } \\
\text { based on the Laplace solution } \\
\text { where gradient solution is obtained } \\
\text { by solving numerically for steady- } \\
\text { state head distribution. }\end{array}$ & $+172 \%$ \\
\hline $3 \mathrm{~B}$ & $\begin{array}{l}\alpha^{*}=0.12 \mathrm{~cm}^{-1} \text { (Elrick et } \\
\text { al. } 1989, \text { Eq. } 13, \text { p. } 186) \\
\text { C factor Eq. } 1, \text { p. } 220, \\
\text { Zhang et al. }(1998)\end{array}$ & $\begin{array}{l}K f s=C Q /\left(2 \pi H^{2}+\pi a^{2} C+2 \pi H / a^{*}\right. \\
\text { When } \alpha^{*}=0.12 \mathrm{~cm}^{-1} \\
\qquad C=\left(\frac{H / a}{2.074+0.093(H / a)}\right)^{0.754}\end{array}$ & $\begin{array}{l}\text { Includes saturated and unsaturated } \\
\text { flow. } C \text { value based on Richards } \\
\text { Eq. includes components of gravity } \\
\text { and capillarity. }\end{array}$ & $-21 \%$ \\
\hline $3 \mathrm{C}$ & $\begin{array}{l}\alpha^{*}=0.04 \mathrm{~cm}^{-1}(\text { Elrick et } \\
\text { al. } 1989, \text { Eq. } 13, \text { p. } 186) \\
\text { C factor Eq. } 2 \text {, p. } 220\end{array}$ & $\begin{array}{l}\quad K f s=C Q /\left(2 \pi H^{2}+\pi a^{2} C+2 \pi H / a^{*}\right. \\
\text { When } \alpha^{*}=0.04 \mathrm{~cm}^{-1}\end{array}$ & $\begin{array}{l}\text { Includes saturated and unsaturated } \\
\text { flow. } C \text { value based on Richards } \\
\text { Eq. includes components of gravity }\end{array}$ & $-57 \%$ \\
\hline
\end{tabular}




\begin{tabular}{|c|c|c|c|c|}
\hline & Zhang et al. (1998) & $C=\left(\frac{H / a}{1.992+0.091(H / a)}\right)^{0.683}$ & and capillarity. & \\
\hline 3D & $\begin{array}{l}\alpha^{*}=0.01 \mathrm{~cm}^{-1} \text { (Elrick et } \\
\text { al. } 1989, \text { Eq. } 13, \text { p. } 186), \\
\text { C factor Eq. } 3 \text {, p. } 220, \\
\text { Zhang et al. }(1998)\end{array}$ & $\begin{array}{l}\begin{aligned} & K f s=C Q /\left(2 \pi H^{2}+\pi a^{2} C+2 \pi H / a^{*}\right. \\
& \text { When } \alpha^{*}=0.01 \mathrm{~cm}^{-1} \\
&$\[ C=\left(\frac{H / a}{2.102+0.118(H / a)}\right)^{0.655} \]$\end{aligned}\end{array}$ & $\begin{array}{l}\text { Includes saturated and unsaturated } \\
\text { flow. } C \text { value based on Richards } \\
\text { Eq. includes components of gravity } \\
\text { and capillarity. }\end{array}$ & $-86 \%$ \\
\hline $4 \mathrm{~A}$ & $\begin{array}{l}\alpha^{*}=\infty, \mathrm{C} \geq 0.12 \mathrm{~cm}^{-1} \\
\text { (Elrick et al. } 1989, \mathrm{Eq} . \\
13, \text { p.186), C factor Eq. } \\
\text { 1, p. 220, Zhang et al. } \\
(1998)\end{array}$ & $\begin{array}{c}K f s=C Q /\left(2 \pi H^{2}+\pi a^{2} C\right. \\
\text { When } \mathrm{C}>0.12 \mathrm{~cm}^{-1} \\
C=\left(\frac{H / a}{2.074+0.093(H / a)}\right)^{0.754}\end{array}$ & $\begin{array}{l}\text { Includes saturated flow with } \\
\text { capillary flow removed. } C \text { value } \\
\text { based on Richards Eq. includes } \\
\text { components of gravity. }\end{array}$ & $+35 \%$ \\
\hline 4B & $\begin{array}{l}\alpha^{*}=\infty, \mathrm{C}=0.04 \mathrm{~cm}^{-1} \\
\text { (Elrick et al. } 1989, \text { Eq. } \\
\text { 13, p.186), C factor Eq. } \\
\text { 2, p. 220, Zhang et al. } \\
\text { (1998) }\end{array}$ & $\begin{array}{r}K f s=C Q /\left(2 \pi H^{2}+\pi a^{2} C\right. \\
\text { When } \mathrm{C}=0.04 \mathrm{~cm}^{-1} \\
C=\left(\frac{H / a}{1.992+0.091(H / a)}\right)^{0.683}\end{array}$ & $\begin{array}{l}\text { Includes saturated flow no } \\
\text { capillary flow. } C \text { value based on } \\
\text { Richards Eq. includes components } \\
\text { of gravity. }\end{array}$ & $+36 \%$ \\
\hline
\end{tabular}

Table 2) Summary of the various solutions used in the sensitivity analysis. $\uparrow$ The Glover solution is normally written:

$K_{f S}=\mathrm{Q}\left(\sinh ^{-1}(H / r)-1\right) / 2 \pi H^{2}$ 


\begin{tabular}{|c|c|c|c|c|c|c|c|c|}
\hline Site ID & $\begin{array}{l}\text { Number of } \\
\text { measurements }\end{array}$ & $\begin{array}{l}\text { Soil depth } \\
\text { (m) }\end{array}$ & $\begin{array}{l}\text { Mean } H \\
(\mathrm{~mm})\end{array}$ & $\begin{array}{l}\text { Mean } a \\
(\mathrm{~mm})\end{array}$ & $\begin{array}{l}\dagger \text { Mean } Q \\
\left(\mathrm{~mm}^{3} \mathrm{~s}^{-1}\right)\end{array}$ & SE & $\begin{array}{l}\operatorname{Max} \cdot Q \\
\left(\mathrm{~mm}^{3} \mathrm{~s}^{-1}\right)\end{array}$ & $\begin{array}{l}\text { Min. } Q \\
\left(\mathrm{~mm}^{3} \mathrm{~s}^{-1}\right)\end{array}$ \\
\hline DW1 & 13 & $0.04-0.15$ & 110 & 36 & 2686 & 764 & 9505 & 166 \\
\hline DW1 & 13 & $0.15-0.25$ & 100 & 34 & 498 & 87 & 1175 & 166 \\
\hline G1 & 13 & $0.04-0.15$ & 110 & 33 & 407 & 182 & 2143 & 60 \\
\hline G1 & 13 & $0.15-0.25$ & 100 & 33 & 194 & 33 & 503 & 83 \\
\hline DW2 & 16 & $0.04-0.15$ & 110 & 34 & 2305 & 536 & 8045 & 617 \\
\hline $\mathrm{G} 2$ & 16 & $0.04-0.15$ & 110 & 34 & 420 & 69 & 1382 & 202 \\
\hline CW3 & 16 & $0.04-0.15$ & 110 & 37 & 889 & 184 & 2886 & 313 \\
\hline G3 & 16 & $0.04-0.15$ & 110 & 36 & 653 & 538 & 2239 & 152 \\
\hline FW4 & 12 & $0.04-0.15$ & 110 & 33 & 154 & 516 & 4812 & 1 \\
\hline G4 & 16 & $0.04-0.15$ & 110 & 32 & 28 & 13 & 216 & 7 \\
\hline G4 & 16 & $0.15-0.25$ & 100 & 33 & 48 & 12 & 199 & 16 \\
\hline
\end{tabular}


Table 3) Site IDs relate to Fig. 1. $H$ is the head height of water in the auger hole, $a$ is the radius of the auger hole, $Q$ is the steady-state rate of water entry into the auger hole, Max. $Q$ is the maximum steady-state infiltration and Min. $Q$ is minimum steady-state infiltration. $\uparrow$ Mean $Q$ is the geometric mean because the $K f_{s}$ is $\log$ normally distributed. 


\begin{tabular}{|c|c|c|c|c|}
\hline Site ID & $\begin{array}{l}\text { Soil depth } \\
\text { (m) }\end{array}$ & $\begin{array}{l}\text { Mean } K f_{S}(3 \mathrm{~A}, 3 \mathrm{~B}, 3 \mathrm{C}) \\
\left(\mathrm{mm} \mathrm{hour}^{-1}\right)\end{array}$ & $\begin{array}{c}\text { Mean } K f s(1) \\
\left(\mathrm{mm} \mathrm{hour}^{-1}\right)\end{array}$ & $\begin{array}{c}\text { Mean } K f s(2 \mathrm{~A}) \\
\left(\mathrm{mm} \mathrm{hour}^{-1}\right)\end{array}$ \\
\hline DW1 & $0.04-0.15$ & $\left(0.36 \mathrm{~cm}^{-1}\right) 120$ & 102 & 130 \\
\hline DW1 & $0.15-0.25$ & $\left(0.36 \mathrm{~cm}^{-1}\right) 23,\left(0.12 \mathrm{~cm}^{-1}\right) 16$ & 21 & 26 \\
\hline G1 & $0.04-0.15$ & $\left(0.36 \mathrm{~cm}^{-1}\right) 18,\left(0.12 \mathrm{~cm}^{-1}\right) 13$ & 18 & 21 \\
\hline G1 & $0.15-0.25$ & $\left(0.12 \mathrm{~cm}^{-1}\right) 7,\left(0.04 \mathrm{~cm}^{-1}\right) 4$ & 8 & 10 \\
\hline DW2 & $0.04-0.15$ & $\left(0.36 \mathrm{~cm}^{-1}\right) 106$ & 98 & 120 \\
\hline G2 & $0.04-0.15$ & $\left(0.12 \mathrm{~cm}^{-1}\right) 14,\left(0.04 \mathrm{~cm}^{-1}\right) 8$ & 18 & 21 \\
\hline CW3 & $0.04-0.15$ & $\left(0.36 \mathrm{~cm}^{-1}\right) 38$ & 34 & 42 \\
\hline G3 & $0.04-0.15$ & $\left(0.12 \mathrm{~cm}^{-1}\right) 21,\left(0.36 \mathrm{~cm}^{-1}\right) 29$ & 26 & 32 \\
\hline FW4 & $0.04-0.15$ & $\left(0.36 \mathrm{~cm}^{-1}\right) 5,\left(0.12 \mathrm{~cm}^{-1}\right) 5$ & 6 & 7 \\
\hline G4 & $0.04-0.15$ & $\left(0.12 \mathrm{~cm}^{-1}\right) 1,\left(0.04 \mathrm{~cm}^{-1}\right) 0.64$ & 2 & 2 \\
\hline G4 & $0.15-0.25$ & $\left(0.04 \mathrm{~cm}^{-1}\right) 1$ & 2 & 3 \\
\hline
\end{tabular}

Table 4) Comparison of geometric mean $K f s$ calculated from Solution 1 (the Glover solution), Solution 2A (the Glover solution corrected for gravity) and Solutions 3A, 3B and 3C (the Richard's equation, using one of the $\alpha^{*}: 0.04 \mathrm{~cm}^{-1}, 0.12 \mathrm{~cm}^{-1}$ and $0.36 \mathrm{~cm}^{-1}$ ) for each site and measured soil layers. $0.01 \mathrm{~cm}^{-1} \alpha^{*}$ is not included, because it was considered that none of the soils fitted into this category. The values in brackets are selected $\alpha^{*}$ values used in the calculation. More than one $\alpha^{*}$ is added to some sites, when it was difficult to define which $\alpha^{*}$ to use where the auger hole intersected more than one soil horizon. 


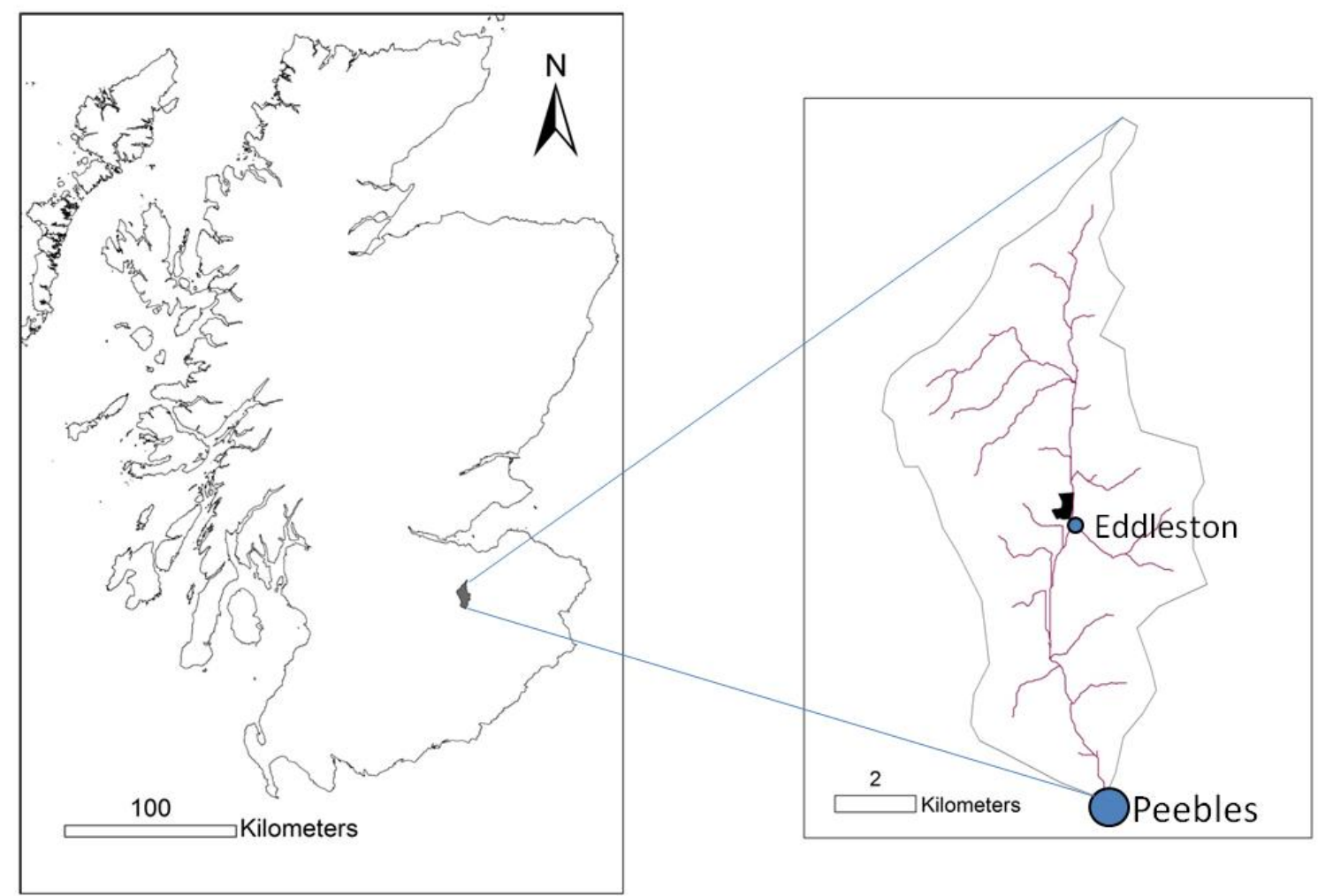

Fig. 1) The location of the field area in Scotland and in the catchment of the Eddleston Water 


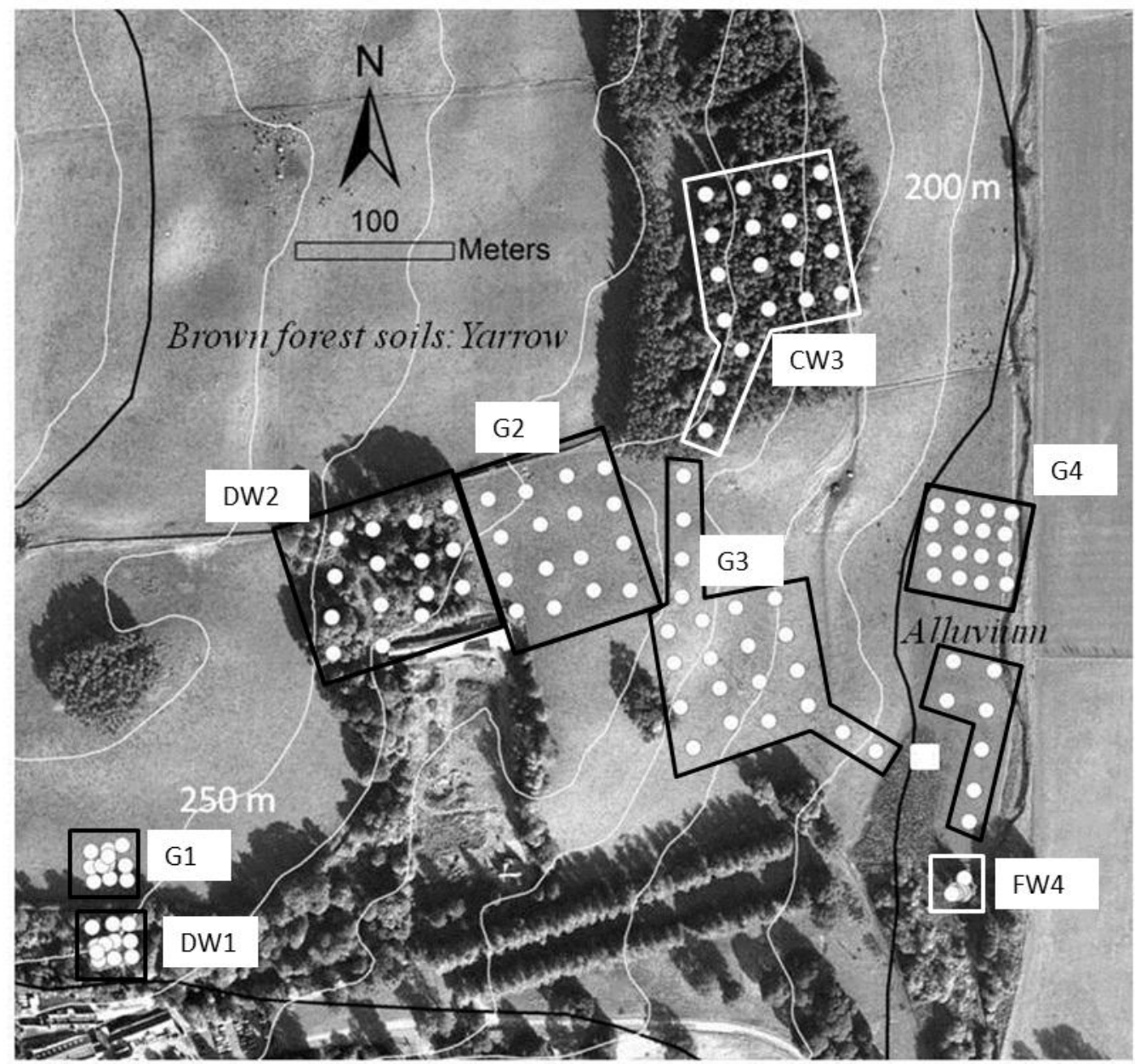

Fig. 2) Aerial photo of site area showing the locations of the CHWP measurements (white circles) and area of auger hole measurements (white square). Four auger hole measurements were carried out within the white square. Ponded disc permeameter measurements (Perroux and White 1988) were undertaken within G4 only. CHWP measurements were taken at two depths ( 0.04 to $0.15 \mathrm{~m}$ and 0.15 to $0.25 \mathrm{~m})$ for DW1, G1 and G4. All other areas were measured at one layer ( 0.04 to $0.15 \mathrm{~m})$. White lines represent contours and the black lines are the delineations of Associations shown in the Peebles soil map: Soil Survey of Scotland, systematic soil survey; sheet $24 \&$ part of sheet 32. Scale 1:250 000 (Soil Survey of Scotland Staff 1975). (C) UKP/Getmapping Licence No. UKP2006/01 


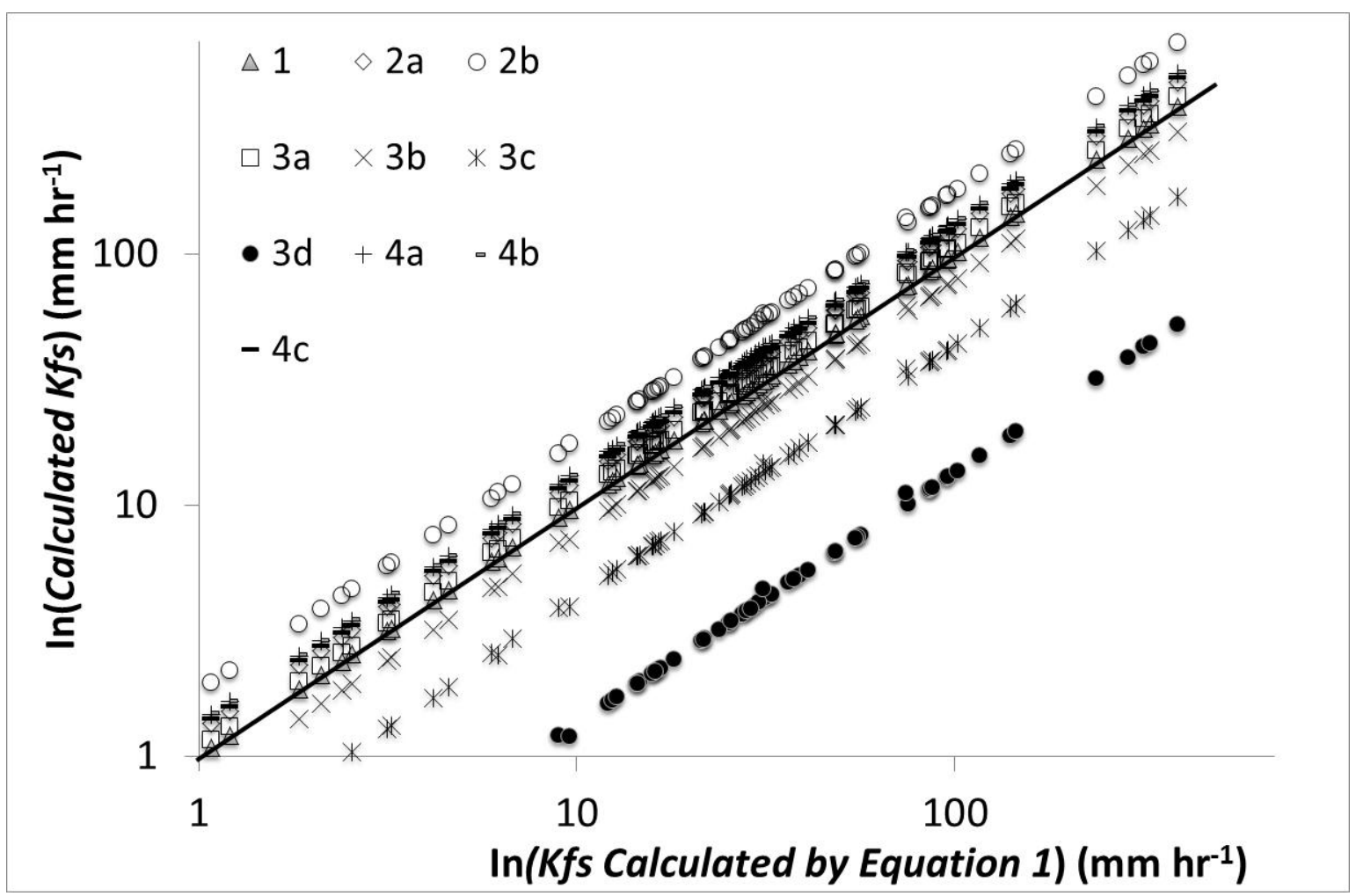

Fig. 3) Comparison of logarithmic $K f S$ values calculated using different formulae described in Table 2 against the Glover solution (Equation 1), shown as 1:1 line. The number of data points was reduced, to provide more clarity to the graphs. 

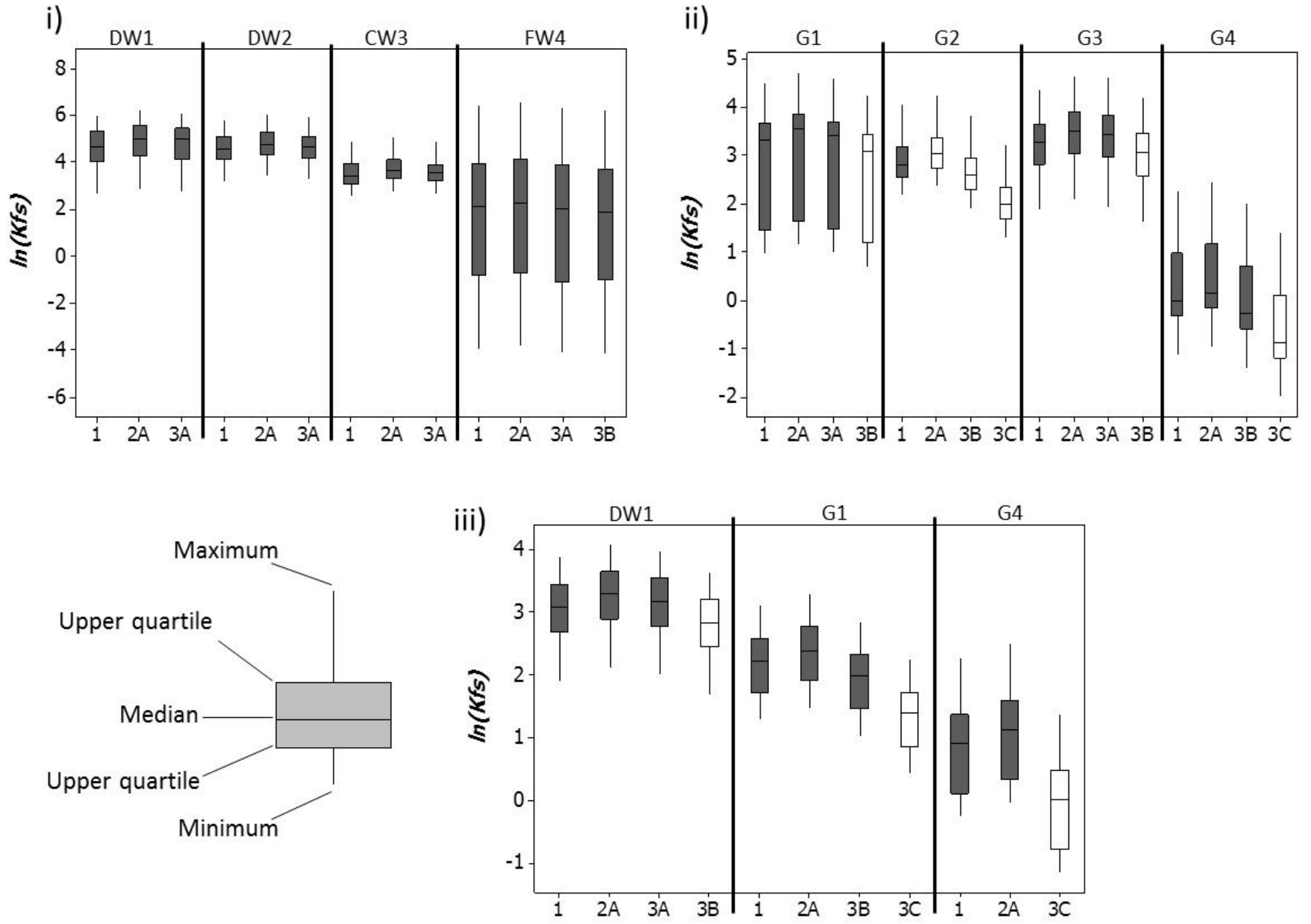
Fig 4) Box plots illustrating $K f s$ values calculated for the different sites (located in Fig. 2) using solutions 1, 2A, 3A, 3B and 3C (as described in Table 2). G1, G2, G3 and G4 are grassland areas and DW1, DW2, CW3 and FW4 are woodland areas and are explained in Table 2. Open box plots have significantly different $(P<0.05)$ mean $K f s$ values within each site group. 


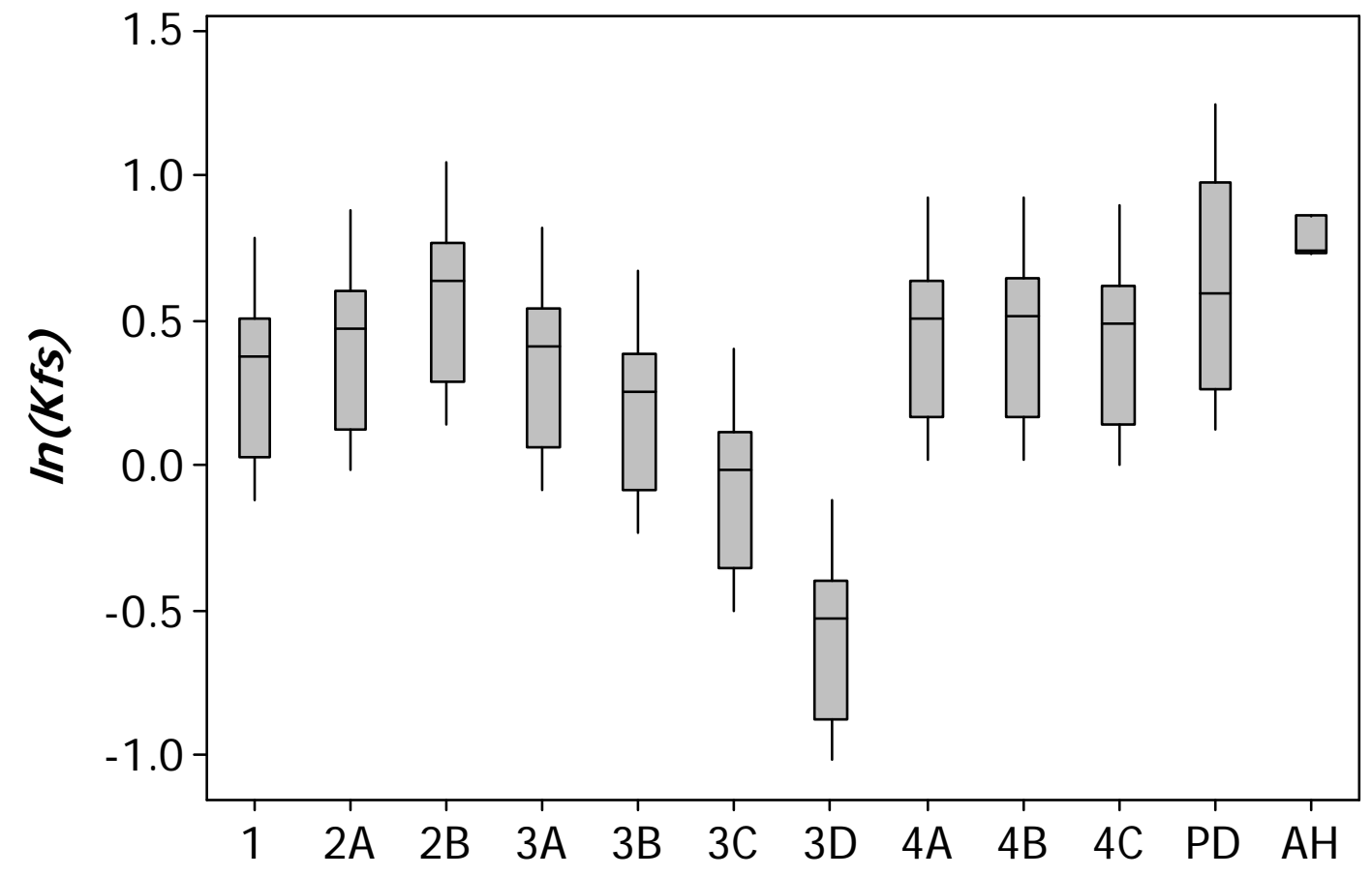

Fig. 5) Box plot comparing log transformed $K f s$ results in the floodplain area (site G4) of the CHWP solutions (1, 2A, 2B, 3A, 3B, 3C, 3D, 4A, 4B, 4C), the ponded disc permeameter (PD) and the auger hole methods (AH). The description for each solution ID is given in Table 2. 